\title{
Corporate Social Responsibility Practice in the Gulf Cooperation Council Countries amidst the COVID-19 Pandemic
}

\author{
http://doi.org/10.21272/bel.4(4).99-104.2020
}

\section{Dr. Ali Alkubaisy, ORCID: https://orcid.org/0000-0002-7033-6365}

$\mathrm{PhD}$, Assistant Professor, Lusail University, Doha, Lusail, Quatar, legal counsel and researcher, member of the Association of Corporate Counsel USA, member of the Arab Lawyers Association, UK

\begin{abstract}
The health, economic, and social consequences of the COVID-19 virus have highlighted the need for collaboration among all agents to face a scenario that we have not before seen. Like the rest of the world, the Gulf Cooperation Council (GCC) with governments of almost all GCC countries have imposed lockdowns, travel restrictions and curfews to deal with the COVID-19 pandemic. Many projects have been extended and operational infrastructure and utility projects face or are expected to face shortages of labour and materials, restriction in movement of personnel and interruption to supply chains. The aims of this paper are to analyze the involvement that emerging markets have shown during the most challenging moments of the epidemic and to determine the objectives these companies have pursued with them. This paper aims to explore corporate legal and social responsibility in the context of the COVID-19 pandemic, especially in emerging economies in the Gulf Cooperation Council (GCC). The paper will clarify CSR's notion and provide an overview of different CSR domains, including legal, financial, social, and ethical domains, and it will discuss the relevance of CSR in emerging economies from the GCC region. Being socially responsible on the part of corporate entities is now no longer an option; it is part of their normal business obligations in human resource management (HRM) and the legal frameworks for employment in GCC. In the context of the COVID-19 pandemic, these frameworks may be exacerbated by-laws limiting circulation in and out of these countries, leading to company collapse and severe social and economic repercussions. Considering these aspects, CSR practice may be applied in the GCC region through a legal framework that would elicit some mandatory CSR actions from corporations, including HRM practices, corporate governance, accountability, and transparency.
\end{abstract}

Keywords: COVID-19 Pandemic, Gulf Cooperation Council Countries, Social Responsibility, Health.

JEL Classification: M14, I15.

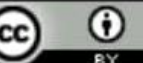

Cite as: Alkubaisy, A. (2020). Corporate Social Responsibility Practice in the Gulf Cooperation Council Countries amidst the COVID-19 Pandemic. Business Ethics and Leadership, 4(4), 99-104. http://doi.org/10.21272/bel.4(4).99-104.2020.

(C) The Author, 2020. This article is published with open access at Sumy State University.

\section{Introduction}

The Coronavirus or COVID-19 has generated significant health, economic, and social risks because we could only use restraints on mobility and economic activity to contain its spread. The crisis resulting from the pandemic has caused a change in how corporations pursue their economic, social, and environmental objectives, giving greater importance to the role they must play in society. In this new scenario, firms need to adopt their CSR strategies to establish a business commitment to society and vulnerable groups, especially those closest to them, the local environment associated with the country of origin of the firms or territories in which companies operate have a greater presence. Therefore, the crisis resulting from the pandemic has caused a change in how corporations pursue their economic, social, and environmental objectives, giving greater importance to the role they must play in society. This paper aims to identify the CSR policies developed by the GCC countries in the face of the pandemic, and the objective is to determine the benefits that firms want to obtain in one of the hardest-hit countries. The theoretical framework is usually designed to categorize business commitments based on identifying five types of business responsibility: economic and legal, commercial, ethical, altruistic, and strategic. However, in today's context, what was seen as discretionary in 
Carroll's CSR hierarchy now became necessary. ${ }^{1}$ Society is facing one of the most challenging times amidst the COVID-19 pandemic, yet this context also offers enterprises a real opportunity to practice valid CSR. ${ }^{2}$

\section{Literature Review}

The relevance of CSR in emerging markets has been extensively discussed in the literature for the past decade. ${ }^{3}$ These ideas converge towards the necessity for an increased CSR practice in emerging economies due to the fragmented natures of markets, underdeveloped legal frameworks, and unstable socio-economic and political conditions. ${ }^{4}$ To this end, it has been argued that companies can use CSR to build their brand by showing accountability and trustworthiness. Concomitantly, others have argued that given the socio-economic context of emerging economies, enterprises conducting their business in these regions have a legal duty to act towards CSR and address accountability and trustworthiness issues. ${ }^{5}$ CSR human resource management is proposed as one way in which this can be addressed. It includes the provision of a fair salary, training and professional development, health and safety at work, as well as transparency and dialog. ${ }^{6}$

The current economic and social scenario requires a redefinition of public and private strategies, decisions, and actions to face globalized threats that can affect freedom of movement and the welfare state, and these situations are common in developing countries. In early 2000, corporate social responsibility (CSR) was defined as the sum of voluntary actions taken by a company to integrate social and environmental concerns in their operations. In 2011, this definition was revised by the European Commission, which defined CSR as the responsibility of a company for the impact that its operations have on society. ${ }^{7}$ Nevertheless, the impacts that the actions of an enterprise can have are diverse. These effects can refer to social aspects and legal, ethical, and economic concerns. ${ }^{8}$ At the other end of the spectrum, any enterprise's fundamental responsibility is to produce acceptable returns for its owners. ${ }^{9}$ Given these perspectives, what CSR should entail generally falls into one of the two schools of thought: on the one hand, companies should act to maximize profits within legal boundaries and minimal ethical constraints; on the other hand, companies should work towards a broader range of obligations towards society. ${ }^{10}$ Archie Carroll, professor at the University of Georgia and theoretician in CRS, was the first who proposed reconciliation between these two views. In his assertion, CRS is: The social responsibility of business encompasses the economic, legal, ethical, and discretionary expectations that society has of organizations at a given point in time. ${ }^{11}$ In one of his later works, Carroll proposed a hierarchy of CRS, starting with the fundamental economic responsibility of an enterprise, moving to the legal requirements of a business, continuing with the expected ethical corporate behaviour and finally, ending with a desired (not required nor expected) behaviour of acting as a good corporate citizen. ${ }^{12}$

\section{Methodology}

GCC countries selected for this study as a case study, which involves a qualitative analysis of CSR practices followed by countries in the GCC region. Qualitative research methods are designed to help reveal a target audience's behavior and perception regarding a particular topic. There are different types of qualitative research methods like an in-depth interview, focus groups, ethnographic research, content analysis, case study research that are usually used. The results of qualitative methods are more descriptive, and the inferences can be drawn quite easily from the data that is obtained. Qualitative research methods originated in the social and behavioral sciences. Today our world is more complicated, and it is difficult to understand what people think and perceive. Online qualitative research methods make it easier to understand that as it is more communicative and descriptive.

\footnotetext{
${ }^{1}$ Schwartz, M. S., and Carroll, A. B. (2003). Corporate Social Responsibility: A Three-Domain Approach. Business Ethics Quarterly, 13(4). DOI: https://doi.org/10.5840/beq200313435

${ }^{2}$ He, H., and Harris, L. (2020). The Impact of Covid-19 Pandemic on Corporate Social Responsibility and Marketing Philosophy. Journal of Business Research, 116. DOI: https://doi.org/10.1016/j.jbusres.2020.05.030.

${ }^{3}$ Leila, C. V., and Fratostiteanu, C. (2018). Corporate Social in Emerging Economies. $1^{\text {st }}$ ed. Routledge, an imprint of Taylor and Francis.

${ }^{4}$ Peters, S., Miller, M., and Kusyk, S. (2011). How Relevant Is Corporate Governance and Corporate Social Responsibility in Emerging Markets? Corporate Governance: The international journal of business in society, 11(4). DOI: 10.1108/14720701111159262.

${ }^{5}$ Li S., and others. (2010). Corporate Social Responsibility in Emerging Markets. 50 Management International Review, 50(5). DOI:10.1007/s11575010-0049-9.

${ }^{6}$ Barrena-Martínez, J., López-Fernández, M., and Miguel Romero-Fernández, M. (2017). Socially Responsible Human Resource Policies and Practices: Academic and Professional Validation. European Research on Management and Business Economics, 23(1). DOI:10.1016/j.iedeen.2016.05.001.

${ }^{7}$ Malecki, C. (2018). Corporate Social Responsibility. Perspectives for Sustainable Corporate Governance. $1^{\text {st }}$ ed. Edward Elgar Publishing. 453 p.

8 . Ibid 1.

${ }^{9}$ Werther, W. B., Chandler, D. (2001). Strategic Corporate Social Responsibility. $1^{\text {st }}$ ed. USA, SAGE.451 p

${ }^{10}$ Ibid 2.

${ }^{11}$ Archie, B. C. (1979). A Three-Dimensional Conceptual Model of Corporate Performance. The Academy of Management Review. JSTOR Journals. https://www.jstor.org/stable/257850?seq=1\#metadata_info_tab_contents. Accessed 25 October 2020.

12 Archie, B. C. (1991). The Pyramid of Corporate Social Responsibility: Toward the Moral Management of Organizational Stakeholders. Business Horizons, 34(4). DOI: https://doi.org/10.1016/0007-6813(91)90005-G.
} 
Case study research. The case study method has evolved over the past few years and developed into a valuable qual research method. As the name suggests, it is used for explaining an organization or an entity. This type of research method is used within several areas like education, social sciences and similar. This method may look challenging to operate. However, it is one of the simplest ways of researching as it involves a deep dive and thorough understanding of the data collection methods and inferring the data.

The Role of CSR in Emerging Economies in GCC Countries. In the context of the COVID-19 pandemic, the legal and ethical responsibilities of enterprises in GCC have changed considerably. Outside the pandemic, corporations would practice HRM within the legal frameworks established by the governments of GCC. Some ethical and social actions have also been noted, such as cooperation with Microsoft to generate employment for young people. ${ }^{13}$ In effect, this also leads to some economic social responsibility, as by employing youth from the community, the enterprises would benefit from the human resource, while people would contribute to the economic engine through production and consumption. During the COVID-19 pandemic, these paradigms have shifted considerably. Firstly, HRM is now caught in the interplay between legal restrictions for working from home, and the ease of restrictions, once infection cases begun to decrease. ${ }^{14}$ To this end, corporations that need employees to be physically present in the organisation need to have several protective measures. There are no current indications, except for the social distancing regulations, of how companies must protect their employees. It indicates that the lack of a strong legal framework leaves this domain at the discretion of the business. Consequently, there is a stringent need for businesses in the GCC region to have internal policies aimed at protecting their employees, while at the same time preserving their economic interests. It is to be noted that this is a matter of ethical concern and a point of economic and social concern. The absence of strict internal policies on disease prevention and control can lead to a further escalation of COVID-19 cases, hospital overcrowding, and resource depletion for the society in which the company activates. Furthermore, acting in a corporate socially irresponsible way would also impact the company's economic potential, as a prolonged crisis can aggravate the financial recession in the area, which would have an impact on consumption and subsequently on company finances.

There have been numerous ethical and social responsible measures in GCC regions concerning the COVID-19 pandemic. Many of these measures are related to the legal framework for workers, society, and the employer's full legal responsibility. In the context of the COVID-19 pandemic, and laws limiting traveling from one country to the next, the corporate social responsibility underlines the fact that the employer is responsible for the welfare of the employee, which thus further indicates during the pandemic, the employer is legally responsible, therefore, obligated, to take mandatory actions for preventing the spread of the disease. Consumer concerns during the pandemic represent another area of interest in this case. Some companies found it necessary to limit consumption due to over-purchases' ethical concerns during the initial panic shopping. ${ }^{15}$ Such actions are contrary to the core attributes of companies in attaining revenues for their owners. Following this logic, companies could have increased prices and production and would have registered significant profits during the shopping sprees. However, consistent data is indicating that companies who took advantage of crises had suffered significant losses in terms of brand image and subsequently in terms of revenue. ${ }^{16}$ Consideration of CSR lines in a situation is regarded as a better long-term solution for fulfilling the enterprise's leading role.

Various transparency issues have also been noted in corporations conducting their business in GCC countries before the emergence of the world pandemic. An investigation into the CSR transparency practices of these organizations noted a significant discrepancy between the company's type (industrial/non-industrial) and disclosure practices in terms of transparent business practices that align with ethical values and respect employees, the environment, and the community. ${ }^{17}$ To this end, industrial companies were more likely to have transparency policies, albeit their involvements in communities are less pronounced. To this end, it is to be noted that while some requirements for disclosure exist in some GCC regions, there are no statutory requirements for disclosure or adherence to the International Financial Reporting Standards. Combined with the fact that highly profitable family businesses dominate the GCC region, the issue of lack of disclosure results

\footnotetext{
${ }^{13}$ Karataş-Ozian, M., Nicolopoulou, K., and Özbilgin, M. (2014). Corporate Social Responsibility and Human Resource Management. $1^{\text {st }}$ ed. England, Cheltenham. 352 p.

${ }^{14}$ Oxford Business Group (2020). 'GCC States Ease Covid-19 Lockdowns and Accelerate Digitalisation'. https://oxfordbusinessgroup.com/news/gccstates-ease-covid-19-lockdowns-and-accelerate-digitalisation. Accessed 25 October 2020

15 Ibid 8.

${ }^{16}$ Dhillon J. S. (2013). Ethical Brand Image \& Corporate Goodwill: Issues \& Challenges. 3 International Journal of Management \& Information Technology, 3(1). DOI:10.24297/ijmit.v3i1.4639.

${ }^{17}$ Khasharmeh, H.A., and Desoky, A.M. (2013). The on-Line Corporate Social Responsibility Disclosures: The Case of The Gulf Cooperation Council (GCC) Countries. Global Review of Accounting and https://www.researchgate.net/publication/272179837_The_Online_Corporate_Social_Responsibility_Disclosures_Evidence_from_the_Gulf_Coopera tion_Council_Countries.AccessedOctober 2020.
} 
in allegations of fraud, and in the end, the company collapses. It inadvertently affects local employment and underlines the necessity for strong corporate governance and disclosure practices. ${ }^{18}$

Despite these aspects, there are several limitations to what CSR can achieve in emerging economies. Firstly, it must be acknowledged that the traditional legal system in GCC countries is based on Sharia law, which reflects a fully developing economy. ${ }^{19}$ Concomitantly, the duty of corporations to act as a good corporate citizen is at the discretion of the enterprise. ${ }^{20}$ This further implies that the organisation has solely discretionary powers to decide whether it will become involved in CSR practices, including ethical work practices. To this end, given that there is no legal bounding to do so, except the regulations imposed for conducting business in the GCC region, what asserts ethical duty in the absence of legal bounding is financial pursuit. Given the proper context, and in the absence of legal bounding disclosure legislation, corporations would also be less likely to disclose their activities and act transparently.

In this sense, an empirical investigation into the CSR practices and disclosure in companies residing in Saudi Arabia found a severe lack of legal frameworks that would bind these companies towards such actions. ${ }^{21}$ Further, there is a consistent trend of setting the whole responsibility of social and economic developments on the state. Noting this aspect, the investigation argues that a formal policy approach to CSR is necessary for the GCC region, as the arbitrary character of CSR in a developed nation is not applicable here due to social and legal contexts. This approach has been taken by the United Arab Emirates, who in 2018, issued the CSR Law, which obligates certain companies to report on their CSR activities. ${ }^{22}$ To this date, the impact of this new legislation on companies and consumer perceptions has not yet been assessed. Nonetheless, previous investigations into UAE companies practicing CSR in terms of HRM do report a positive behavioural shift in employees, which is further reflected in corporate productivity. ${ }^{23}$ Qatari companies strongly believe that social responsibility is social responsibility is a key pillar of the business environment. Therefore, constant efforts are made to support and encourage the social responsibility initiatives and programs that positively reflect the social and humanitarian levels inside the Qatari society. Qatar recently solidified its position as a growing hub for CSR initiatives, more and more Qatari companies are now implementing their corporate social responsibility (CSR) initiatives as part of their strategy to build a positive brand image in rapidly evolving markets. ${ }^{24}$

Corporate Social Responsibility in the GCC is developing to meet the requirements of the region's changing socio-economic map. Corporations, large and small, need to acknowledge that they are embedded within the societies in which they conduct their business. When a crisis emerges, most often than not, corporations will seek government support to sustain their business. To this end, various GCC countries have provided economic aid packages to SMEs conducting business in their country. ${ }^{25}$ There have also been several reports of companies that donated significant amounts and materials to support pandemic control efforts. These actions may indicate that during crises, companies may be more inclined towards CSR practices, especially as related to addressing social issues, which may inevitably affect their business capacities.

\section{Results}

The COVID-19 pandemic has generated global health, economic, and social crises that require all agents' collaboration and commitment, especially those in the private sector, to face the epidemic's externalities. In this unfavourable environment, the commitment that companies have with the GCC 2030 vision Agenda and the Sustainable Development Goals (SDGs) has caused them to expand their CSR strategy to fight COVID-19. In this paper, we have analyzed the commitment of the GCC to face the human, health, and economic consequences that this epidemic has for the population. More concretely, the main issue is to identify the CSR actions that these firms have been developed with the aim to determine the objective pursued with them and the benefits that firms want to obtain. It has become apparent that the focus has been somewhat one-sided in nature, with the bulk of attention going to the corporate processes due to the COVID-19 pandemic, and

\footnotetext{
${ }^{18}$ Ramady, M.A. (2012). The GCC Economies. $1^{\text {st }}$ ed. New York, Springer. 324 p.

${ }^{19}$ Ibid 4.

${ }^{20}$ Ibid 11

${ }^{21}$ Mandurah, S., Khatib, J., and Al-Sabaan, S. (2012). Corporate Social Responsibility Among Saudi Arabian Firms: An Empirical Investigation. Journal of Applied Business Research, 28(5). DOI: https://doi.org/10.19030/jabr.v28i5.7244.

${ }^{22}$ Ministry of Economy. (2018), 'Corporate Social Responsibility'. Economy.gov.ae. https://www.economy.gov.ae/english/pages/csruae.aspx. Accessed October 2020.

${ }^{23}$ Cherian, J., and Pech, R. (2017). The Impact of Corporate Social Responsibility on The Workforce of Selected Business Firms in The United Arab Emirates: A Nascent Economy. Sustainability, 9(11). DOI: 10.3390/su9112077.

${ }^{24}$ Lugo-Ocando, J. (2020). CSR evolves as a brand building strategy. The Peninsula. https://thepeninsulaqatar.com/article/28/01/2020/CSR-evolvesas-a-brand-building-strategy. Accessed October 2020.

${ }^{25}$ Nagraj, A. (2020). Gulf Businesses. https://www.magzter.com/article/Business/Gulf Business /SPECIAL-REPORT-CSR. Accessed October 2020.
} 
therefore it is expected that a significant economic recession will follow. This implies that corporations will face the challenge of passing through this crisis. In the absence of clear practice, and valid assets, their collapse is imminent. This aspect thus underlines the importance of disclosure for maintaining good corporate practice, and the necessity for corporate governance, where the board of directors is independent of CEOs and company owners.

\section{Conclusion}

Since the business sector is playing a leading role in development process in any country, GCC members should enhance a clear strategy regarding the corporate social responsibility. This policy mainly reflects the members state`s philosophy in achieving the business sector objectives in line with holding a responsible attitude towards the society. CSR practice in GCC countries may be applied with some limitations as imposed by the legal and social context, but also by the voluntary nature of CSR. In these frameworks, corporates should be clearly acting ethically towards social responsibility, towards disclosure practices and towards developing internal CSR policies. To this end, given the special context of GCC as developing economies, one potential way to address these limitations is by imposing a legal framework for CSR, and by formalising these endeavours, rather than allowing discretionary responsibilities to companies. From a practical point of view, GCC must know that the pandemic will increase society's expectations of companies and their decisions must focus on investing in CSR actions that allow achieving, mutually and interdependently, economic, environmental, and social objectives. Strategies that will ensure the long-term continuity of the companies, by balancing profitability and stakeholders' harmony. In sum, CSR strategies can be a useful and effective tool to face the global problems of the pandemic, limiting the social externalities derived from the effects of COVID-19 and the security measures that it requires. Ethical managers and good corporate governance mechanisms would be unquestionable in this regard.

Funding: There is no funding for this research.

\section{References}

1. Barrena-Martínez, J., López-Fernández, M., and Romero-Fernández, P. (2017). Socially Responsible Human Resource Policies and Practices: Academic and Professional Validation. European Research on Management and Business Economics, 23(1), 55-61. https://doi.org/10.1016/j.iedeen.2016.05.001.

2. Budhwar, P., Pereira, V., Mellahi, K., Singh, S.K. (2018). The State of HRM In the Middle East: Challenges and Future Research Agenda. Asia Pacific Journal of Management, 36, 905-933. Available at: https://link.springer.com/article/10.1007/s10490-018-9587-7.

3. Carroll, A.A. (1979). Three-Dimensional Conceptual Model of Corporate Performance. The Academy of Management Review, 4(4), 497-505. https://doi.org/10.2307/257850.

4. Carroll, A. (1991). The Pyramid of Corporate Social Responsibility: Toward the Moral Management of Organizational Stakeholders. Business Horizons, 34(4), 39-48. DOI: 10.1016/0007-6813(91)90005-G.

5. Cherian, J., and Pech, R. (2017). The Impact of Corporate Social Responsibility on the Workforce of Selected Business Firms in the United Arab Emirates: A Nascent Economy. Sustainability, 9(11), 2077. DOI:10.3390/su9112077.

6. Dr Jairo Lugo-Ocando (2020). CSR evolves as a brand building strategy. The Peninsula, 28 January 2020. Available at: https://thepeninsulaqatar.com/article/28/01/2020/CSR-evolves-as-a-brand-building-strategy.

7. Kerr, S. (2018, June 2018). Cayman Court Finds Saudi Companies Complicit In \$126Bn Fraud. Financial Times. Available at: https://www.ft.com/content/0ec19150-65a4-11e8-90c2-9563a0613e56.

8. He, H., and Harris, L. (2020). The Impact of Covid-19 Pandemic on Corporate Social Responsibility and Marketing Philosophy. Journal of Business Research, 116, 176-182. doi:10.1016/j.jbusres.2020.05.030.

9. Karataş-Özkan M., Nicolopoulou, K., and Özbilgin, M. (2014). Corporate Social Responsibility and Human Resource Management, ISBN 1848447930. 334 p. Available at: https://search.library.utoronto.ca/details?9877582.

10.Khasharmeh, H., and Desoky, A. (2013). On-Line Corporate Social Responsibility Disclosures: The Case of the Gulf Cooperation Council (GCC) Countries. Global Review of Accounting and Finance, 4(2), 39-64. Available https://www.researchgate.net/publication/272179837 The Online Corporate Social Responsibility Dis closures Evidence from the Gulf Cooperation Council Countries.

11.Li, S., Fetscherin, M., Lattemann, C., Alon, I. (2010). Corporate Social Responsibility in Emerging Markets. Management International Review, 50(5), 635-654. DOI:10.1007/s11575-010-0049-9. 
12.Malecki, C. (2018). Corporate Social Responsibility, Edward Elgar Publishing. ISBN:978 1786433343. 480 p. Available at: https://www.e-elgar.com/shop/gbp/corporate-social-responsibility9781786433343.html.

13.Mandurah, S., Khatib, J., and Al-Sabaan, S. (2012). Corporate Social Responsibility among Saudi Arabian Firms: An Empirical Investigation. Journal of Applied Business Research (JABR), 28(5), 1049-1058. DOI:10.19030/jabr.v28i5.7244.

14.Ministry of Economy. Corporate Social Responsibility. Available at: https://www.economy.gov.ae/english/Knowledge-Section/SDGs/Pages/CSR.aspx. Accessed 19 June 2020.

15.Nagraj, A. (2020). Special Report: CSR. Gulf Businesses. Available at: https://www.magzter.com/article/Business/Gulf-Business/SPECIAL-REPORT-CSR. Accessed 19 June 2020.

16.Oxford Business Group (2020). GCC States Ease Covid-19 Lockdowns and Accelerate Digitalisation. Available at: https://oxfordbusinessgroup.com/news/gcc-states-ease-covid-19-lockdowns-and-acceleratedigitalisation.

17.Peters, S., Miller, M., and Kusyk, S. (2011). How Relevant Is Corporate Governance and Corporate Social Responsibility in Emerging Markets? Corporate Governance: The international journal of business in society, 11(4), 429-445. DOI:10.1108/14720701111159262.

18.Ramady, M. (2012). The GCC Economies. Springer New York. Available at: https://www.springerprofessional.de/en/the-gcc-economies/1822360.

19.Schwartz, M., and Carroll, A. (2003). Corporate Social Responsibility: A Three-Domain Approach. Business Ethics Quarterly, 13(4), 503-530. Available at: https://www.researchgate.net/profile/Archie Carroll/publication/261827186 Corporate Social Responsi bility A Three-Domain Approach/links/54a17ab80cf267bdb902c00f/Corporate-Social-ResponsibilityA-Three-Domain-Approach.pdf.

20.Singh Dhillon, D. (2013). Ethical Brand Image \& Corporate Goodwill: Issues \& Challenges. International Journal of Management \& Information Technology, 3(1), 46-53. DOI:10.24297/ijmit.v3i1.4639.

21.Voinea, C., and Fratostiteanu, C. (2018). Corporate Social Responsibility in Emerging Economies. Routledge Studies in Business Ethics. 200 p. DOI:10.4324/9781315112411.

22.Werther, W., and Chandler, D. (2011). Strategic Corporate Social Responsibility (SAGE 2011). Business Horizons, 48(4), 317-324. DOI:10.1016/j.bushor.2004.11.009. 